\title{
ДОКУМЕНТОЗНАВСТВО. АРХІВОЗНАВСТВО
}

УДК 006.034:002.1:352.07](477)

\section{Цитування:}

Анісімова О. М., Лукаш Г. П., Вишинська І. П. Місце та роль ДСТУ 4163:2020 «Уніфікована система організаційно-розпорядчої документації. Вимоги до оформлення документів» у системі чинних документів із справочинства. Бібліотекознавство. Документознавство. Інформологія. 2021. № 4. C. 5-14.

Anisimova O., Lukash H., Vyshynska I. (2021). Place and role of DSTU 4163: 2020 «Unified system of organizational and management documentation. requirements for documentation» in the system of the documents. Library science. Record Studies. Informology. 4, 5-14 [in Ukrainian].
Анісімова Ольга Миколаӥвна, доктор економічних наук, професор, завідувач кафедри інформаційних систем управління Донецького національного університету імені Василя Стуса o.anisimova@donnu.edu.ua https://orcid.org/0000-0002-8016-9361

Лукаш Галина Павлівна, доктор філологічних наук, професор, професор кафедри інформаційних систем управління Донецького національного університету імені Василя Стуса g.lukash@donnu/edu/ua https://orcid.org/0000-0002-9777-7718

Вишинська Ірина Павлівна, здобувач вищої освіти 2 курсу СО «Магістр» спеціальності 029 «Інформаційна, бібліотечна та архівна справа» Донецького національного університету імені Василя Стуса didur_i@donnu.edu.ua https://orcid.org/0000-0002-6476-4451

\section{МІСЦЕ ТА РОЛЬ ДСТУ 4163:2020 «УНІФІКОВАНА СИСТЕМА ОРГАНІЗАЦІЙНО- РОЗПОРЯДЧОЇ ДОКУМЕНТАЦЇ̈. ВИМОГИ ДО ОФОРМЛЕННЯ ДОКУМЕНТІВ» У СИСТЕМІ ЧИННИХ ДОКУМЕНТІВ ІЗ СПРАВОЧИНСТВА}

Мета роботи - з'ясувати значення державного стандарту щзодо оформлення документів ДСТУ 4163:2020 у системі чинних документів із справочинства та уніфікації документних текстів; проаналізувати новий державний стандарт ДСТУ 4163:2020 у порівнянні з його аналогом 2003 року, Постановою КМУ, виявити розбіжності в їхніх текстах та внести пропозицї шуодо їх усунення. Уход $i$ дослідження підкреслено, щуо ией ДСТУ, як і решта національних стандартів, з плином часу втратив свій обов'язковий юридичний статус $і$ став рекомендаційним, а постанови КМУ продовжують зберігати свою обов 'язковість для виконання. Методологія дослідження спирається на застосування принципів системності, науковості та історизму і дає змогу простежити розвиток нормативної документації. Класичні методи аналізу, синтезу та порівняння допомагають зіставити тексти кількох документів, створюючи систему наукової інформаџї. Саме иляхом використання спеціальних та загальнофілософських методів дослідження постає можливим аналіз нормативних документів у контексті їхньої практичності та релевантності. Наукова новизна дослідження полягає у визначенні особливостей вимог до оформлення документів у новому стандарті та обтрунтуванні їх дочільності щзодо актуальних потреб. Проведено порівняльний аналіз текстів документів і виявлено невідповідності оформлення прикладів та тексту ДСТУ. Висновки. Головною особливістю та відмінністю ДСТУ 4163:2020 від інших документів, щзо визначали порядок та вимоги до оформлення документів, є його 
поширення на усі види документації, що створюються у діяльності різних організацій, незалежно від їх носія. Новий стандарт є удосконаленим відповідно до вимог сьогодення, акиентуючи увагу не лише на паперових документах, а й на електронних, оскільки вони зараз посідають провідне місие у будьякій діяльності.

Ключові слова: діловодство, уніфікаиія документних текстів, державний стандарт, електронний документ.

Anisimova Olha,

Doctor of Economic Sciences, professor, Information Systems of Management Department

Vasyl Stus' Donetsk National University

Lukash Halyna,

Doctor of Philological Sciences, professor, Information Systems of Management Department,

Vasyl Stus' Donetsk National University

Vyshynska Iryna,

2nd year higher education applicant (Master's), specialty 029 "Information, Library and Archival Studies,"

Vasyl Stus Donetsk National University

\section{PLACE AND ROLE OF DSTU 4163: 2020 «UNIFIED SYSTEM OF ORGANIZATIONAL AND MANAGEMENT DOCUMENTATION. REQUIREMENTS FOR DOCUMENTATION» IN THE SYSTEM OF THE DOCUMENTS}

The purpose of the article is to find out the significance of the state standard for the design of documents DSTU 4163: 2020 in the system of valid documents on reference and unification of documentary texts; to analyze the new state standard DSTU 4163: 2020 in comparison with its analog of 2003, the Resolution of the Cabinet of Ministers, to identify discrepancies in their texts and to make proposals for their elimination. The study emphasizes that this DSTU, like other national standards, over time has lost its binding legal status and has become a recommendation, and the resolutions of the Cabinet of Ministers continue to be binding. The methodology of research is based on the application of the principles of systematicity, scientificity, and historicism and makes it possible to trace the development of normative documentation. Classical methods of analysis, synthesis, and comparison help to compare the texts of several documents, creating a system of scientific information. It is through the use of special and general philosophical research methods that it is possible to analyze normative documents in the context of their practicality and relevance. The scientific novelty of the study is to determine the features of the requirements for the design of documents in the new standard and justify their feasibility in relation to current needs. The comparative analysis of texts of documents is carried out and discrepancies of registration of examples and the text of DSTU are revealed. Conclusions. The main feature and difference of DSTU 4163: 2020 from other documents that determine the procedure and requirements for the execution of documents is its extension to all types of documentation created in the activities of various organizations, regardless of their carrier. The new standard has been improved to meet today's requirements, focusing not only on paper documents but also on electronic ones, as they now occupy a leading position in any activity.

Keywords: office work, unification of documentary texts, state standard, electronic document. 
Актуальність теми дослідження. Сучасна трансформація суспільства вимагає переосмислення впливу науково-технічного прогресу на всі сфери життєдіяльності. Із розвитком новітніх технологій відбуваються зміни й у процесі діловодства: документи на паперових носіях поступово відходять на другий план, а основним стає їх використання в електронній формі. Запровадження досягнень сучасних наукових інноваційних технологій у діловодчу практику потребує належного законодавчого нормування та регулювання. Закон України «Про діловодство», який би заповнив цю лакуну, досі не прийнятий, є лише Розпорядження КМУ «Про схвалення Концепції проекту Закону України “Про справочинство”» від 26 липня 2006 р. № 426. Документом, що покликаний підвищити ефективність регламентації нових змін та удосконалити нові вимоги до оформлення документів на державному рівні, міг би стати ДСТУ 4163:2020 «Уніфікована система організаційно-розпорядчої документації. Вимоги до оформлення документів» [1], введений Наказом Українського науково-дослідного і навчального центру проблем стандартизації, сертифікації та якості № 144 від 01.07.2020 [9]. У цій ситуації актуальність дослідження нового державного стандарту, визначення його особливостей та встановлення відповідності сучасним умовам не викликає сумнівів.

Аналіз досліджень і публікацій. Над питаннями вивчення уніфікації управлінської документації працювали: I. Є. Антоненко, В. В. Бездрабко, О. М. Загорецька, М. В. Комова, С. Г. Кулешов, Ю. І. Палеха, М. С. Слободяник. Так, значним $є$ внесок С. Г. Кулешова: дослідник $\epsilon$ автором першого в Україні навчального посібника 3 управлінського документознавства, де виокремлено поняття управлінський документ, документування та ін. 3 урахуванням нових тенденцій розвитку діловодства висвітлив проблеми управлінського документування Ю. І. Палеха, подавши його як результат розвитку і самовдосконалення цілісної комунікативної системи, вияв вищої потреби об'єкта управління у певному рівні впорядкування, зрештою, - як культуру операційної управлінської технології [10]. I. С. Антоненко уперше в українському документознавстві дослідила понятійний апарат, законодавчу й нормативну бази, особливості та проблеми діловодства за кордоном на різних етапах його розвитку впродовж кінця XX - початку XXI ст. Причини актуалізації діловодної проблематики наприкінці XX ст. грунтовно проаналізувала О. М. Загорецька. Вона називає такі фактори: ускладнення управлінських функцій; упровадження електронно-обчислювальної техніки в усі сфери людської діяльності; необхідність раціональної організації діловодства в установі з метою економії робочого часу, ефективності реалізації управлінських завдань і рішень; успішне комбінування різних напрямів роботи 3 документами [3].

Мета дослідження - 3'ясувати значення державного стандарту щодо оформлення документів ДСТУ 4163:2020 «Уніфікована система організаційно-розпорядчої документації. Вимоги до оформлення документів» у системі чинних документів із справочинства та уніфікації документних текстів, проаналізувати його особливості й відповідність вимогам сьогодення у зіставленні з документами зазначеного спрямування, внести пропозиції щодо усунення розбіжностей у текстах згаданих документів.

Виклад основного матеріалу. В усьому світі важливу роль у діяльності будь-якої організації відіграють документи, оскільки незалежно від напряму, у якому вона здійснює цю діяльність, iї результатом є створення значної кількості документації, від правильного оформлення, використання та організації якої залежить ефективність роботи підприємства в цілому. Цей фактор зумовлює важливість правильної організації діловодства на підприємстві, що забезпечує координування на всіх етапах роботи підприємства.

Правила та норми оформлення документів закріплено на державному рівні у низці документів, наприклад, у державних стандартах. Довгий час при створенні документів організації керувались стандартом ДСТУ 4163:2003 «Уніфікована система організаційно-розпорядчої документації. Вимоги до оформлювання документів», що поширювався на організаційно-розпорядчу документацію, створювану у процесі діяльності як органів державної влади, місцевого самоврядування, так і у діяльності інших підприємств та організацій [2]. Розглянемо детальніше зміни, що були введені у новому державному стандарті. Новий стандарт повинен усунути розбіжності, які виникли, зокрема між Постановою Кабінету Міністрів України «Деякі питання документування управлінської діяльності» [14] і ДСТУ 4163:2003. 
ДСТУ 4163:2020 було розроблено технічним комітетом стандартизації «Інформація та документація» разом із Українським науково-дослідним Інститутом архівної справи та документознавства. У порівнянні із стандартом 2003 року новий стандарт має значно ширшу дію: він охоплює не лише організаційно-управлінську документацію, а й інфор- маційно-аналітичну, незалежно від функціонального призначення, та є обов'язковим для використання у діяльності державних органів, органів місцевого самоврядування, інших організацій та установ незалежно від виду їх діяльності $[1,2]$. До питань, що їх встановлює ДСТУ 4163:2020, можна віднести такі, що наведені на рисунку 1.

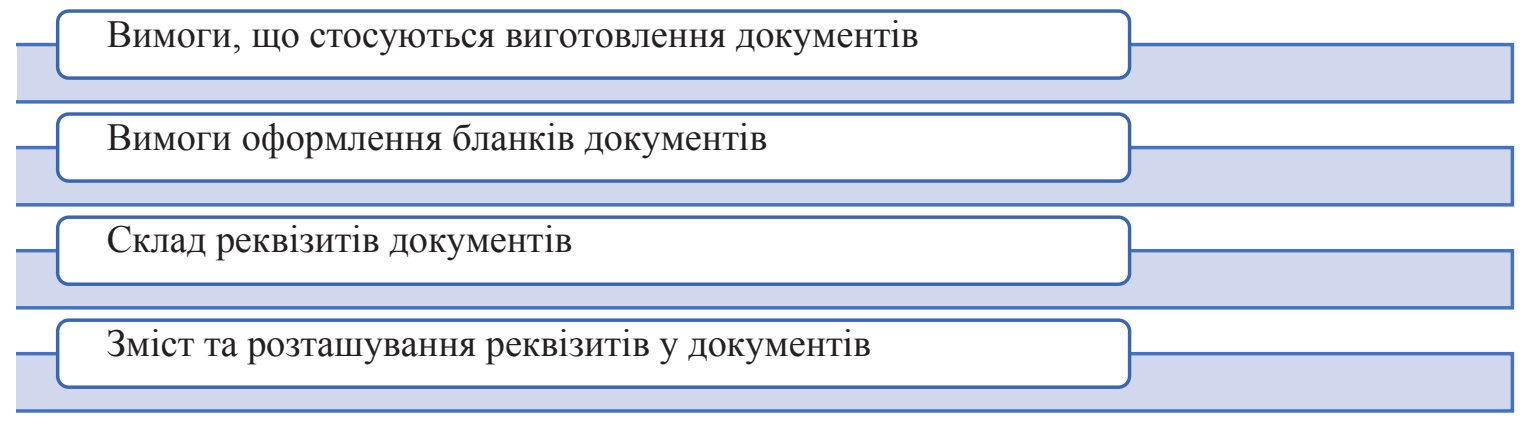

Рисунок 1. Вимоги, що встановлюе ДСТУ 4163:2020

Ще однією відмінною особливістю нового державного стандарту є те, що його дія поширюється не лише на паперові документи, а й на бухгалтерську та електронну документацію. Така зміна зумовлена тим, що 3 розвитком суспільства усі процеси та механізми підлягають автоматизації та інформатизації, i будь-яка документна діяльність не стає винятком. Попередній стандарт поширював свою дію лише на паперові документи [4].
Окрім того, зміни відбулись і в реквізитах документів. Змінився їхній склад та нумерація. Зокрема, реквізит, що стосується зображення нагород, було прибрано із переліку, а також було додано новий реквізит - відмітка про ознайомлення 3 документом. Відбулись зміни й в оформленні існуючих раніше документів, що наведено у таблиці 1. 
Таблиия 1

\section{Вимоги до оформлення реквізитів документів згідно із ДСТУ 4163:2020}

\begin{tabular}{|c|c|c|c|}
\hline № & Назва реквізиту & $\begin{array}{c}\text { Назва та номер } \\
\text { реквізиту за ДСТУ } \\
\text { 4163:2003 }\end{array}$ & Зміни у оформленні \\
\hline 1 & $\begin{array}{l}\text { Зображення } \\
\text { Державного Герба } \\
\text { України, Герба АР } \\
\text { Крим }\end{array}$ & $\begin{array}{l}\text { Зображення } \\
\text { Державного Герба } \\
\text { України, Герба АР } \\
\text { Крим, №1 }\end{array}$ & $\begin{array}{l}\text { Дозволено розміщувати на бланках документів органів } \\
\text { місцевого самоврядування та інших юридичних осіб. } \\
\text { Розміщення Герба АР Крим дозволено лише поруч із } \\
\text { Гербом України. }\end{array}$ \\
\hline 2 & $\begin{array}{l}\text { Зображення емблеми } \\
\text { юридичної особи або } \\
\text { торговельної марки }\end{array}$ & $\begin{array}{l}\text { Зображення емблеми } \\
\text { юридичної особи або } \\
\text { торговельної марки, } \\
\text { №2 }\end{array}$ & $\begin{array}{l}\text { Дозволено розміщувати з лівого боку від найменування } \\
\text { юридичної особи або на площі, відведеній для розмі- } \\
\text { щення реквізитів } 3,4,5 \text {. } \\
\text { Заборонено розміщення, якщо на бланку є зображення } \\
\text { гербів, не дозволяється використовувати на заміну } \\
\text { реквізиту } 4 \text {. }\end{array}$ \\
\hline 3 & $\begin{array}{l}\text { Найменування юри- } \\
\text { дичної особи вищого } \\
\text { рівня }\end{array}$ & $\begin{array}{l}\text { Назва організації } \\
\text { вищого рівня, №6 }\end{array}$ & $\begin{array}{l}\text { Дозволено зазначати скорочено, якщо це затверджено } \\
\text { офіційно. }\end{array}$ \\
\hline 4 & $\begin{array}{l}\text { Найменування } \\
\text { юридичної особи }\end{array}$ & $\begin{array}{l}\text { Назва організацій, } \\
\text { №7 }\end{array}$ & $\begin{array}{l}\text { Дозволено використовувати напівжирний шрифт при } \\
\text { оформленні. }\end{array}$ \\
\hline 5 & $\begin{array}{l}\text { Найменування } \\
\text { структурного підроз- } \\
\text { ділу юридичної особи }\end{array}$ & $\begin{array}{l}\text { Назва структурного } \\
\text { підрозділу } \\
\text { організації, №8 }\end{array}$ & $\begin{array}{l}\text { Дозволено використовувати напівжирний шрифт при } \\
\text { оформленні. }\end{array}$ \\
\hline 6 & $\begin{array}{l}\text { Довідкові дані про } \\
\text { юридичну особу }\end{array}$ & $\begin{array}{l}\text { Довідкові дані про } \\
\text { організацію, №9 }\end{array}$ & $\begin{array}{l}\text { Визначено конкретну послідовність розміщення } \\
\text { реквізитів поштової адреси та номерів телефону; } \\
\text { Дозволено розміщувати адресу юридичного та фактичного } \\
\text { розміщення організації, якщо вони мають відмінності. }\end{array}$ \\
\hline 7 & Код форми документа & $\begin{array}{l}\text { Код форми } \\
\text { документи, №5 }\end{array}$ & $\begin{array}{lcccc}\text { Проставляється } & \text { відповідно } & \text { до } & \text { НК } & 010: 2021 \\
\text { «Класифікатор управлінської документації» } & \end{array}$ \\
\hline 8 & Код юридичної особи & Код організації, №4 & $\begin{array}{l}\text { Уточнено місце розміщення відповідно до бланку } \\
\text { документа, дозволено використовувати шрифт у 8-12 д. п. }\end{array}$ \\
\hline 9 & Назву виду документа & $\begin{array}{l}\text { Назва виду } \\
\text { документа, №10 }\end{array}$ & Дозволено використовувати шрифт у 14-16 д. п. \\
\hline 10 & Дата документа & Дата документа, №11 & $\begin{array}{l}\text { Дозволено проставляти у спільних документах двох чи } \\
\text { більше юридичних осіб дату проставлення останнього } \\
\text { підпису; у використанні ІС дозволено проставляти дату } \\
\text { у складі штрих-коду та визначено вимоги до цього виду } \\
\text { розміщення дати. } \\
\text { Зазначено, що датуванню підлягають усі службові } \\
\text { відмітки, проставлені на документі }\end{array}$ \\
\hline 11 & $\begin{array}{l}\text { Реєстраційний індекс } \\
\text { документа }\end{array}$ & $\begin{array}{l}\text { Реєстраційний індекс } \\
\text { документа, №12 }\end{array}$ & $\begin{array}{l}\text { Зазначено необхідність відділення складників індексу } \\
\text { правобічною похилою рискою. } \\
\text { Визначено вимогти до оформлення реквізиту у разі } \\
\text { використання IC у складі штрих-коду. }\end{array}$ \\
\hline 12 & $\begin{array}{l}\text { Посилання на } \\
\text { реєстраційний індекс і } \\
\text { дату документа }\end{array}$ & $\begin{array}{l}\text { Посилання на реєстра- } \\
\text { ційний індекс і дату } \\
\text { документа, №13 }\end{array}$ & $\begin{array}{l}\text { Вказано необхідність розміщення нижче або на рівні } \\
\text { реєстраційного індексу. }\end{array}$ \\
\hline 13 & $\begin{array}{l}\text { Місце складання } \\
\text { документа }\end{array}$ & $\begin{array}{l}\text { Місце складення або } \\
\text { видання документа, } \\
\text { №14 }\end{array}$ & 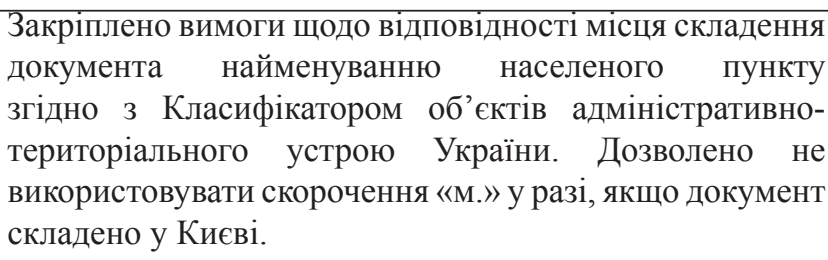 \\
\hline
\end{tabular}




\begin{tabular}{|c|c|c|c|}
\hline 1 & 2 & 3 & 4 \\
\hline 14 & $\begin{array}{l}\text { Триф обмеження } \\
\text { доступу до документа }\end{array}$ & $\begin{array}{l}\text { Гриф обмеження } \\
\text { доступу до } \\
\text { документа, №15 }\end{array}$ & Уточнено деталі оформлення. \\
\hline 15 & Адресат & Адресат, №16 & Уточнено деталі оформлення. \\
\hline 16 & $\begin{array}{l}\text { Гриф затвердження } \\
\text { документа }\end{array}$ & $\begin{array}{l}\text { Гриф затвердження } \\
\text { документа, №17 }\end{array}$ & Визначено деталі оформлення за різних обставин. \\
\hline 17 & Резолюція & Резолюція, №18 & $\begin{array}{l}\text { Визначено, що становить собою резолюція, та уточнено } \\
\text { вимоги до ії оформлення. }\end{array}$ \\
\hline 18 & Відмітка про контроль & $\begin{array}{l}\text { Відмітка про } \\
\text { контроль, №20 }\end{array}$ & Уточнено деталі оформлення. \\
\hline 19 & $\begin{array}{l}\text { Заголовок до тексту } \\
\text { документа }\end{array}$ & $\begin{array}{l}\text { Заголовок до тексту } \\
\text { документа, №19 }\end{array}$ & $\begin{array}{l}\text { Дозволено використовувати напівжирний шрифт при } \\
\text { оформленні. }\end{array}$ \\
\hline 20 & Текст документа & $\begin{array}{l}\text { Текст документа, } \\
\text { №21 }\end{array}$ & Уточнено деталі оформлення. \\
\hline 21 & $\begin{array}{l}\text { Відмітка про } \\
\text { наявність додатків }\end{array}$ & $\begin{array}{l}\text { Відмітка про } \\
\text { наявність додатків, } \\
\text { №22 }\end{array}$ & $\begin{array}{llcc}\text { Введено термін «Додаток довідкового характеру», } \\
\text { відмітка позначається у правому верхньому куті } \\
\text { першого аркуша додатку. }\end{array}$ \\
\hline 22 & Підпис & Підпис, №23 & $\begin{array}{l}\text { Дозволено замінювати усі підписи на електронний } \\
\text { підпис у разі, якщо це електронний документ. } \\
\text { У документах на інших носіях змінено вимоги до } \\
\text { оформлення із зазначення прізвища та ініціалів на } \\
\text { зазначення власного імені та прізвища у документах. }\end{array}$ \\
\hline 23 & Відбиток печатки & $\begin{array}{l}\text { Відбиток печатки, } \\
\text { №26 }\end{array}$ & $\begin{array}{l}\text { Уточнено вимоги оформлення в електронних } \\
\text { документах: заміна відбитків печатки на електронну } \\
\text { печатку, що створюється відповідно до вимог Законів } \\
\text { України. }\end{array}$ \\
\hline 24 & Віза документа & Візи документа, №25 & Уточнено деталі оформлення. \\
\hline 25 & $\begin{array}{l}\text { Гриф погодження } \\
\text { документа }\end{array}$ & $\begin{array}{l}\text { Гриф погодження } \\
\text { документа, №24 }\end{array}$ & $\begin{array}{l}\text { Розширено від лише погодження до схвалення. } \\
\text { Уточнено деталі оформлення. }\end{array}$ \\
\hline 26 & $\begin{array}{l}\text { Відмітка про } \\
\text { засвідчення копії }\end{array}$ & $\begin{array}{l}\text { Відмітка про засвід- } \\
\text { чення копії, №27 }\end{array}$ & $\begin{array}{l}\text { Уточнено відповідно до зміни вимог до оформлення } \\
\text { реквізиту «Підпис». }\end{array}$ \\
\hline 27 & $\begin{array}{l}\text { Відомості про } \\
\text { виконавця документа }\end{array}$ & $\begin{array}{l}\text { Гриф погодження } \\
\text { документа, №24 }\end{array}$ & Дозволено використовувати шрифт у 8-12 д. п. \\
\hline 28 & $\begin{array}{l}\text { Відмітка про } \\
\text { ознайомлення } 3 \\
\text { документом }\end{array}$ & $\begin{array}{l}\text { Відмітка про } \\
\text { засвідчення копії, } \\
\text { №27 }\end{array}$ & $\begin{array}{l}\text { Визначено вимоги до оформлення: розміщується } \\
\text { нижче реквізиту «Підпис» або «Віза документа», } \\
\text { можливе зазначення конкретного виду документа } \\
\text { замість слова «документ»; складається зі слів «із } \\
\text { документом ознайомлений», власного підпису, імені та } \\
\text { дати ознайомлення. }\end{array}$ \\
\hline 29 & $\begin{array}{l}\text { Відмітка про } \\
\text { виконання документа }\end{array}$ & $\begin{array}{l}\text { Гриф погодження } \\
\text { документа, №24 }\end{array}$ & Уточнено вимоги до оформлення. \\
\hline 30 & $\begin{array}{l}\text { Відмітка про } \\
\text { надходження } \\
\text { документа до } \\
\text { юридичної особи }\end{array}$ & $\begin{array}{l}\text { Відмітка про } \\
\text { засвідчення копії, } \\
\text { №27 }\end{array}$ & $\begin{array}{l}\text { Замінено слово «надійдення» на «надходження». } \\
\text { Дозволено оформляти у складі штрих-коду у разі } \\
\text { використання ІС. }\end{array}$ \\
\hline 21 & $\begin{array}{l}\text { Запис про державну } \\
\text { реєстрацію }\end{array}$ & $\begin{array}{l}\text { Гриф погодження } \\
\text { документа, №24 }\end{array}$ & $\begin{array}{l}\text { Дозволено проставляти у складі QR-коду у разі } \\
\text { використання IC. Змінено вимоги до оформлення. }\end{array}$ \\
\hline 32 & $\begin{array}{l}\text { Відмітка про } \\
\text { наявність примірника } \\
\text { з паперовим носієм } \\
\text { інформації }\end{array}$ & $\begin{array}{l}\text { Відмітка про } \\
\text { засвідчення копії, } \\
\text { №27 }\end{array}$ & $\begin{array}{l}\text { Визначено вимоги до оформлення: проставлення } \\
\text { штрих-коду, що містить скорочене найменування } \\
\text { юридичної особи, дату реєстрації та індекс, а також } \\
\text { відомості про підписанта документа тощо. }\end{array}$ \\
\hline
\end{tabular}


У результаті проведеного порівняльного аналізу вимог до оформлення реквізитів документів у ДСТУ 4163:2020 та ДСТУ 4163:2003 можна побачити, що зміни спрямовані більше на оформлення документів в електронній формі, оскільки зараз відбувається перехід до електронного документообігу і паперові документи все менше використовуватимуться у діяльності різних підприємств та організацій. Такі зміни виникли у результаті інформатизації та відповідного впровадження нових автоматизованих інформаційних систем 3 метою спрощення та пришвидшення процесів діяльності людини, зменшення витрат часу на підготовку документів, їх обліку, передачі, умов зберігання тощо [12, 43; $15 ; 16,356]$.

Окрім того, важливими змінами в оформленні реквізитів документів є введення ново- го реквізиту «Відмітка про ознайомлення 3 документом» та зміни у оформленні реквізиту «Підпис», що полягають у зазначенні власного імені та прізвища замість ініціалів та прізвища. Така зміна зумовлена наближеністю до вимог, що диктують міжнародні стандарти, оскільки вони не передбачають використання «по батькові», а лише власного імені та прізвища.

Ще одним важливим нововведенням у державному стандарті 2020 року є введення вимог до кеглів шрифту. У стандарті, що був чинним із 2003 року, не були визначені вимоги до варіативності розмірів шрифту у документах. У новому ж стандарті вказано на необхідність використання шрифту Times New Roman, кегль 12-14 [1]. Уточнимо головні зміни (рис. 2). Отже, ДСТУ 4163:2020:

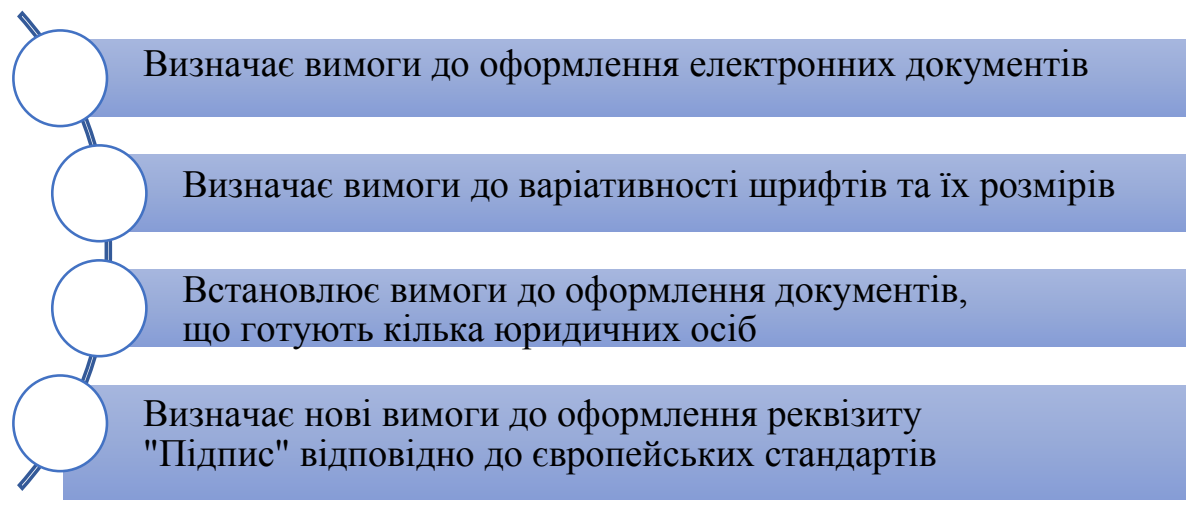

Рисунок 2. Головні зміни, що введені із набуттям чинності ДСТУ 4163:2020

Підсумовуючи, звернімо увагу на наявність розбіжностей у чинних документах, якими ми на сьогодні маємо керуватися у діловодстві: Постанова КМУ «Деякі питання документування управлінської діяльності» від 17 січня 2018 р. № 55 і ДСТУ 4163:2020. Зауважимо перед цим, що частина 2 ст.23 Закону України «Про стандартизацію» говорить про те, що «Національні стандарти та кодекси усталеної практики застосовуються на добровільній основі, крім випадків, якщо обов'язковість їх застосування встановлена нормативно-правовими актами» [7]. ДСТУ 4163:2020 не є нормативно-правовим актом. Якщо постанови КМУ обов'язкові для ви- конання, то ДСТУ, як і решта національних стандартів, втратив свій обов'язковий юридичний статус і став рекомендаційним, «стандарт став нині певною мірою "громадською угодою"» [17]. «Якщо раніше у стандартах «СИБИД» («Система стандартов по информации, библиотечному и издательскому делу») писали «обязателен для применения в научной, учебной, методической литературе», то нині у національних стандартах зазначено: «застандартизовані терміни рекомендовано вживати...» [11, 23].

Уточнимо наші пропозиції щодо усунення розбіжностей у текстах згаданих документів: 
1. Необхідно внести зміни до Постанови, де у Загальних вимогах щодо створення документів п. 9 досі зазначено, що «Під час підготовки організаційно-розпорядчих документів у паперовій формі працівники установ оформлюють їх з урахуванням вимог ДСТУ 4163-2003».

2. У реквізиті «Відмітка про контроль» тексту ДСТУ 4136-2020 не написано про використання червоного або іншого яскравого кольору.

3. Слід доповнити вказівку щодо розміщення додатків довідкового характеру до основного документа у верхньому правому куті першого аркуша додатку, уточнивши відступ у мм.

4. Виправити такі, на нашу думку, невдалі приклади щодо реквізиту «Підпис»:

а) у наведених зразках власне ім'я розташоване на рівні першого рядка посади, хоча п. 7.5 ДСТУ зазначає необхідність його розташування на рівні останнього рядка;

б) у прикладах посада подана $з$ відступом, хоча у тексті ДСТУ (п. 7.7) зазначено, що відступ не роблять;

в) інколи прізвище у прикладах розташоване не на одному рядку з власним ім'ям;

г) не поданий приклад щодо підписання спільного документа особами, які займають однакові посади.

5. ДСТУ суперечить Постанові щодо оформлення грифу погодження. У ДСТУ з'явилось слово ПОГОДЖУЮ за наявності особистого підпису та власного імені та прізвища. Постанова використовує ПОГОДЖЕНО у всіх варіантах.

6. $Є$ різночитання щодо оформлення копії документів: у Постанові зазначено, що Відмітка «Копія» проставляється у верхньому правому кутку першої сторінки паперового документа, тоді як у ДСТУ це не зазначено.

7. У реквізиті «Відомості про виконавця документа» у додатках до ДСТУ в номері телефону $є$ код міста, але за текстом в обох документах у прикладах коди міст відсутні.

8. Суперечливими є твердження про те, як оформлювати реквізит «Назва виду документа»: у Постанові шрифт розміром 14, напівжирним, у ДСТУ 14-16 та розріджений шрифт, про напівжирний не згадано.
9. У ДСТУ реквізити «Найменування юридичної особи вищого рівня», «Найменування юридичної особи» необхідно друкувати великими літерами, тоді як в Постанові про це нічого не сказано.

10. $€$ розбіжності у друкуванні документів непостійного строку зберігання. У ДСТУ зазначено, що їх можна друкувати на лицьовому і зворотному боці аркуша, а у постанові додаються обмеження: обсяг більше 20 сторінок та при цьому реквізит «Підпис» повинен бути розміщений на лицьовому, а не на зворотному боці останнього аркуша документа.

11. Приклади надано достатньо інформативні, але вони подані не шрифтом Times New Roman, хоча саме про цей шрифт йдеться в п. 7.2 ДСТУ.

Усі ці недоліки не дозволять пересічному громадянину з повним розумінням оформлювати документацію.

Наукова новизна дослідження полягає у визначенні особливостей у вимогах до оформлення документів у новому стандарті та обгрунтуванні їх доцільності відносно потреб сьогодення. Детально проаналізовано новий державний стандарт ДСТУ 4163:2020 у порівнянні з його аналогом 2003 року, Постановою КМУ та визначено практичне застосування і пропозиції з усунення розбіжностей у їхніх окремих позиціях.

Висновки. Особливістю ДСТУ 4163:2020 $€$ його спрямованість на оформлення електронної документації та зміні старих вимог, їх удосконаленні відповідно до європейських стандартів. Це пов'язано із виходом документообігу та діловодства на новий, електронний, рівень у зв'язку із інформатизацією. Такі зміни дають змогу полегшити та пришвидшити роботу з документами, спростити умови їх створення, передачі, зберігання. Можна iз впевненістю стверджувати, що введення в дію нового стандарту (після усунення розбіжностей) $\epsilon$ важливим кроком у розвитку питання впровадження електронного документообігу та діловодства в Україні та їі виходу на новий рівень інформатизації, який відкриває значно нові можливості.

Перспективи сучасного стану діловодства полягають у подальшій розробці та забезпеченні організації діловодства в Україні, 
a саме: прийнятті Закону України «Про діловодство»; роботі над нормативно-правовими актами, що регулюють організацію електронного діловодства; стандартизації правових документів України з міжнародними. Зрозумілим $є$ те, розроблення нових стандартів - це лише частина складного, багатогранного процесу, пов'язаного $з$ їх упровадженням. 3 метою постійного оновлення стандартів, встановлення потреби перегляду їх чи скасування відповідно до правил ISO, чинні стандарти мають розглядатися кожні п’ять років.

\section{Список використаних джерел}

1. Уніфікована система організаційно-розпорядчої документації. Вимоги до оформлення документів: ДСТУ 4163:2020. Київ : Держспоживстандарт України, 2020. 37 с.

2. Державна уніфікована система документації. Уніфікована система організаційно-розпорядчої документації. Вимоги до оформлювання документів: ДСТУ 4163-2003. Київ : Держспоживстандарт України, 2003. 22 с.

3. Загорецька О.М. Нормативне та науково-методичне забезпечення організації діловодства в Україні у другій половині XX - на початку XXI ст.: автореф. дис... канд. іст. наук: 07.00.10 Київ, 2005. 16 с.

4. Закон України «Про електронні документи та електронний документообіг». Верховна Рада України. URL: http://zakon0.rada.gov.ua/laws/show/851-15 (дата звернення: 17.09.2020)

5. Закон України «Про інформацію». Верховна Рада України. URL: http://zakon2.rada.gov.ua/laws/ show/2657-12 (дата звернення: 17.09.2020)

6. Закон України «Про Національний архівний фонд і архівні установи». Верховна Рада України. URL: http://zakon3.rada.gov.ua/laws/show/3814-12 (дата звернення: 17.09.2020)

7. Закон України «Про стандартизацію». URL: https://zakon.rada.gov.ua/laws/show/1315-18 (дата звернення: 19.08.20201)

8. Наказ Міністерства юстиції України від 18.06.2015 № 1000/5 «Про затвердження Правил організації діловодства та архівного зберігання документів у державних органах, органах місцевого самоврядування, на підприємствах, в установах і організаціях». URL: https://zakon.rada.gov.ua/laws/show/ z0736-15\#Техt (дата звернення: 21.08.2020)

9. Наказ Українського науково-дослідного і навчального центру проблем стандартизації, сертифікації та якості № 144 (v0144774-20) від 01.07.2020. URL: https://zakon.rada.gov.ua/rada/show/v005560903/ sp:side:max15?sp=:side:max15\&lang=ru\#Text.(дата звернення: 27.08.2020)

10.Палеха Ю. І. Управлінське документування: у 2 ч. Ч.1. Ведення загальної документації (зі зразками сучасних ділових паперів): навч. посібник. Київ : Професіонал, 2001. 327 с.

11.Пасічник Л. Облік стандартів: пошукові можливості друкованих та електронних джерел. Вісник Книжкової палати. 2012. № 7. С. 22-25.

12.Писаренко В. П. Упровадження електронного документування в органах державної влади та місцевого самоврядування. Публічне адміністрування: теорія та практика. 2012. Вип. 2. С. 43-54.

13.Постанова Кабінету Міністрів України від 14.04.1997 № 348 «Про затвердження Інструкції з діловодства за зверненнями громадян в органах державної влади і місцевого самоврядування, об'єднаннях громадян, на підприємствах». URL: https://ips.ligazakon.net/document/KP970348?an=1 (дата звернення: 10.09.2020)

14.Постанова КМУ «Деякі питання документування управлінської діяльності» від 17 січня 2018 p. № 55 URL: https://zakon.rada.gov.ua/laws/show/55-2018-\%D0\%BF\#Text (дата звернення: 11.09.2020)

15.Про затвердження Порядку роботи з електронними документами у діловодстві та їх підготовки до передавання на архівне зберігання : наказ Міністерства юстиції України № 1886/5 від 11.11.2014; зареєстровано в Міністерстві юстиції України 11.11.2014 № 1421/26198. URL: http://zakon4.rada.gov.ua/ laws/show/z1421-14(дата звернення: 11.09.2020)

16.Пронь Н. О. Вимоги до електронних документів: міжнародна практика та досвід України. Збірник наукових праць Національного університету державної податкової служби України. 2012. № 1. С. 356-366. URL: http://nbuv.gov.ua/UJRN/znpnudps_2012_1_36 (дата звернення: 07.08.2020)

17. Солоіденко Г. Стандартизація у бібліотечній галузі: підсумки 26-річної діяльності. Наукові праці Національної бібліотеки України імені В. I. Вернадського. 2017. Вип. 48. С. 32-44. URL: http:// irbis-nbuv.gov.ua/everlib/item/er-0002799 (дата звернення: 17.09.2020) 


\section{References}

1. Unified system of organizational and administrative documentation. Requirements for paperwork. (2020). DSTU 4163:2020. Kyiv: Derzhspozhyvstandart Ukrainy [in Ukrainian].

2. State unified documentation system. Unified system of organizational and administrative documentation. Requirements for paperwork. (2003). DSTU 4163-2003. Kyiv: Derzhspozhyvstandart Ukrainy [in Ukrainian].

3. Zahoretska O.M. (2005). Regulatory and scientific and methodological support for the organization of office work in Ukraine in the second half of XX - early XXI century. Kyiv [in Ukrainian].

4. Law of Ukraine "On electronic documents and electronic document management". URL: http:// zakon0.rada.gov.ua/laws/show/851-15. [in Ukrainian].

5. Law of Ukraine "On Information". Verkhovna Rada of Ukraine. URL: http://zakon2.rada.gov.ua/laws/ show/2657-12 [in Ukrainian].

6. Law of Ukraine "On the National Archival Fund and Archival Institutions". URL: http://zakon3.rada. gov.ua/laws/show/3814-12. [in Ukrainian].

7. Law of Ukraine "On Standardization". URL: https://zakon.rada.gov.ua/laws/show/1315-18. [in Ukrainian].

8. Order of the Ministry of Justice of Ukraine dated 18.06.2015 № 1000/5 "On approval of the Rules for the organization of record keeping and archival storage of documents in state bodies, local governments, enterprises, institutions and organizations." URL: https://zakon.rada.gov.ua/laws/show/z0736-15\#Text.

9. Order of the Ukrainian Research and Training Center for Standardization, Certification, and Quality № 144 dated 01.07.2020. URL: https://zakon.rada.gov.ua/rada/show/v005560903/sp:side:max15?sp=:side:max 15\&lang=ru\#Text.

10.Palekha Yu.I. (2001). Management documentation: at 2 p.m. Part 1 Maintaining general documentation (with samples of modern business papers): textbook. Manual. Kyiv: Profesional. [in Ukrainian].

11.Pasichnyk L. (2012). Accounting standards: search capabilities of printed and electronic sources. Visnyk Knyzhkovoi palaty, 7. 22-25 [in Ukrainian].

12. Pysarenko V. P. (2012). Introduction of electronic documentation in public authorities and local governments. Publichne administruvannia: teoriia ta praktyka, 2. 43-54 [in Ukrainian].

13. Resolution of the Cabinet of Ministers of Ukraine of 14.04.1997 № 348 "On approval of the Instruction on record keeping on appeals of citizens in public authorities and local governments, associations of citizens, at enterprises". URL: https://ips.ligazakon.net/document/KP970348?an=1. [in Ukrainian].

14.Resolution of the Cabinet of Ministers of Ukraine "Some issues of documenting management activities" of January 17, 2018, № 55. URL: https://zakon.rada.gov.ua/laws/show/55-2018-\%D0\%BF\#Text. [in Ukrainian].

15. On approval of the Procedure for working with electronic documents in office work and their preparation for transfer to archival storage: order of the Ministry of Justice of Ukraine № 1886/5 dated 11.11.2014. URL: http://zakon4.rada.gov.ua/laws/show/z1421-14. [in Ukrainian].

16.Pron N.O. (2012). Requirements for electronic documents: international practice and experience of Ukraine. Zbirnyk naukovykh prats Natsionalnoho universytetu derzhavnoi podatkovoi sluzhby Ukrainy, 1. 356-366. URL: http://nbuv.gov.ua/UJRN/znpnudps_2012_1_36 [in Ukrainian].

17. Soloidenko, H. (2017). Standardization in the library industry: the results of 26 years of activity. Naukovi pratsi Natsional'noyi biblioteky Ukrayiny imeni V. I. Vernads'koho, 48, 32-44. URL: http://nbuviap. gov.ua/index.php?option $=$ com_content\&view $=$ article \&id=3433:standartizatsiya-u-bibliotechnij-galuzipidsumki-26-richnoji-diyalnosti $\&$ catid $=81 \&$ Itemid $=415$ [in Ukrainian]. 